\title{
DEVELOPMENT OF A METHOD FOR PRODUCING NEW GENERATION OF PROTEIN SNACKS USING THE PROCESSES OF CRYO AND MECHANICAL DISTRUCTION
}

\author{
Viktoriya Pogarskaya ${ }^{1}$ \\ viktoria.pogarskaya@ukr.net \\ Olga Yurieva ${ }^{1}$ \\ olyaureva@ukr.net \\ Aleksey Pogarskiy ${ }^{T}$ \\ valve310@gmail.com \\ Kateryna Balabai ${ }^{1}$ \\ ekaterinabala@email.uat \\ Nadiya Maksymoval \\ kapochka48@gmail.com \\ Klochkivska str., 333, Kharkov, Ukraine, 61051
}

${ }^{1}$ Department of Food Technologies of Products from Fruits

Vegetables and Milk and Innovations in Health Nutrition

Kharkov State University of Food Technology and Trade

\begin{abstract}
The aim of research is to develop a method for the production of a new generation of protein snacks using a protein vegetable and milk base and vegetable fortifiers from spicy and carotene-containing vegetables using cryo and mechanical destruction processes. The method is based on the use of a deep processing method as an innovation, which consists in a complex effect on vegetable and protein raw materials of cryo and mechanical destruction processes in modern quick-freezing and low-temperature crushing equipment. The proposed method allows to get new protein snacks with a high content of protein, BAR and phytocomponents in an easily digestible form.

A new generation of protein snacks has been developed to strengthen the immune system using cryogenic protein base and vegetable raw materials. Nano-additives from dried peas and specially processed soft brine cheese are used as a protein base. Pea nanoadditives obtained using non-enzymatic catalysis - mechanolysis, mechanical destruction contain 21.5 ... $23.0 \%$ of complete protein, which includes $49 \%$ of amino acids in a bound state and $51 \%$ in a free state. During the special processing of soft brine cheese with the help of mechanical destruction, $50 \ldots 55 \%$ of the bound amino acids of the protein are transformed into free $\alpha$-amino acids in an easily digestible form.

The proposed method makes it possible to more fully reveal the biological potential of vegetable and protein raw materials, to transform protein, BAS and phytocomponents in a bound form into easily digestible nanocomponents into a free easily digestible form. In addition, the processed protein base and raw materials acquire new properties structure formation, gelation, coloring ability.

The obtained protein snacks are natural, differ from the traditional ones by their high content of complete protein and the absence of synthetic impurities (preservatives, thickeners, colorants, etc.). In addition, $100 \mathrm{~g}$ of new products can satisfy the daily requirement for biologically active substances ( $\beta$-carotene, L-ascorbic acid, phenolic compounds).
\end{abstract}

Keywords: vegetable processing, protein snacks, vegetable fortifiers, health products, pea nano-additives.

DOI: $10.21303 / 2504-5695.2021 .001877$

\section{Introduction}

The relevance of the studies presented in the work is associated with the need to solve the problem of reducing the immunity of the population [1-3]. It can be increased by including in the daily diet of combined dairy and vegetable products containing a significant amount of biologically active substances (BAS) and phytocomponents of plant raw materials [4-5], and also have a significant content of complete protein $[6,7]$. Powdered milk and milk whey have traditionally been used as a dairy base in the manufacture of such products [8]. Recently, legume flour has been used as a milk base and a 
source of protein $[9,10]$. Powders, pastes, frozen additives, concentrates from various types of fruit and vegetable raw materials are used as enrichment of recipe components [11]. Among the combined dairy and vegetable products that are popular among the population, one can distinguish protein snacks spreads, the protein base of which is made up of additives from legumes, as well as processed fermented milk cheeses [12]. The main disadvantages of such combined products are the low content of complete protein, biologically active substances [13], high fat content and the presence of harmful food additives in the composition (structure-formers, transgenic fats, flavors, dyes, etc.) [14, 15], which correspond in organoleptic attractiveness, and short shelf life of the product [11, 16, 17]. The low content of biologically active substances is associated with the use in the manufacture of enriching prescription components in the form of powders, pastes, frozen additives from fruit and vegetable raw materials of traditional technologies [18]. Losses of BAR when receiving additives from fruit and vegetable raw materials using traditional technologies range from 20 to $80 \%$ [19].

A promising raw material for enriching herbal supplements is spicy, carotene-containing vegetables (sweet peppers, carrots, pumpkin, tomatoes, parsley root, garlic) and natural spices, the therapeutic and prophylactic properties of which are well known [13, 14].

One of the promising directions of processing raw fruits and vegetables is "shock" freezing with subsequent storage at a temperature of $18^{\circ} \mathrm{C}[20,21]$. The analysis of literature data on the study of the effect of freezing temperature regimes on the quality of the product in terms of the content of biologically active substances, organoleptic, thermophysical indicators. It has been established that the disadvantage of the most common method of "shock" freezing by a flow of cold air is the loss of vitamins and other biologically active substances, as well as the loss of cell sap during thawing [22]. It has been shown that the loss of BAS and cell sap during thawing of the product depends on the freezing rate [23, 24]. The higher the speed, the less the violation of the cellular structure of fruit and vegetable raw materials and the less the loss of BAS [25] and cell juice [26] during defrosting [27, 28]. In leading countries, to obtain high-quality frozen products, "shock" freezing is used using cryogenic liquids (nitrogen, carbon dioxide). The analysis of the data showed that there is little information in the scientific literature about the effect of cryogenic "shock" freezing and fine grinding [29] of fruit and vegetable raw materials when receiving additives for biochemical, physicochemical, microbiological processes, cryo and mechanical destruction processes [30]. The exception is the results of fundamental and applied research obtained by the authors of this work for some types of fruit and vegetable raw materials [13].

The aim of research is to develop a method for obtaining a new generation of protein snacks to strengthen immunity using a specially processed protein base and vegetable fortifiers with a high content of amino acids, BAS and phytocomponents in an easily digestible nanoscale form. The new method is based on the use as an innovation of a complex effect on the protein and raw materials of cryoprocessing and the processes of cryo and mechanical destruction. They occur in modern quick-freezing and low-temperature crushing equipment (at a temperature of $35^{\circ} \mathrm{C}$ ), which makes it possible to obtain a new generation of protein snacks to increase immunity.

\section{Materials and Methods}

The study was carried out at the Kharkiv State University of Food Technology and Trade (KSUFTT, Ukraine) on the basis of the research laboratory "Innovative cryo and nanotechnologies of herbal supplements and health products" of the Department of Food Technologies of Products from Fruit, Vegetables and Milk and Innovations in Health Nutrition.

As research materials, when developing a new method for the production of protein snacks, the following were chosen: nano-additives from peas and specially processed soft brine cheese in an easily digestible form as a protein base; sweet pepper, parsley root, garlic, carrots, pumpkin, tomatoes and vegetable cryo-frozen fortifiers obtained from them; a new generation of natural protein snacks to strengthen the immune system "Bogatyr", "Carotone", "Svitliachok" (Fig. 1).

Cryogenic freezing was carried out using a cryogenic freezer using liquid and gaseous nitrogen as a refrigerant [9]. For fine grinding, let's use homogenizer-grinders made in France "Robot Couper" and an innovative food processor "ThermoMix" (France) [13]. Steam-thermal processing in the manufacture of protein snacks was carried out using modern Italian-made equipment a UNOX vapor convection oven of the XVC series [9]. 


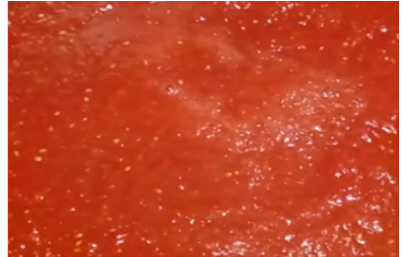

$a$

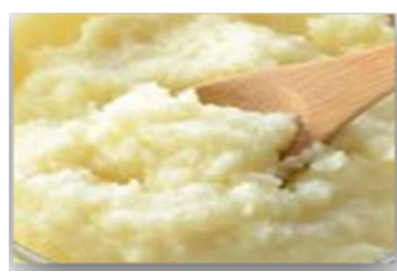

$d$

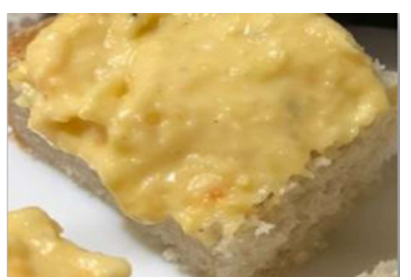

$g$

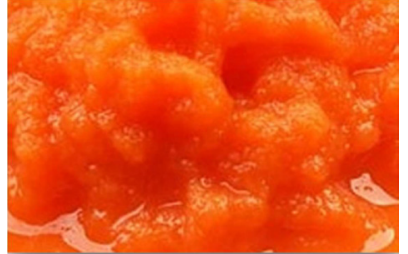

b

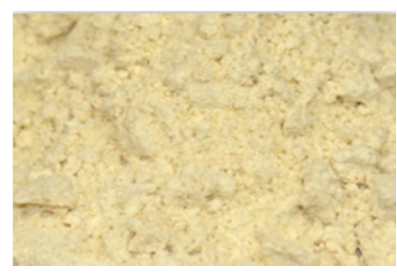

e

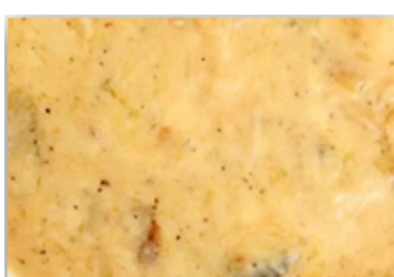

$h$

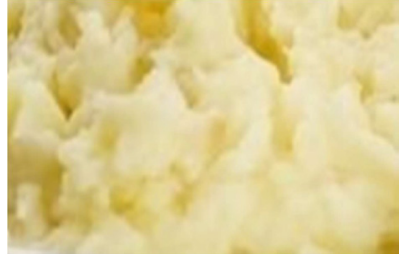

$c$

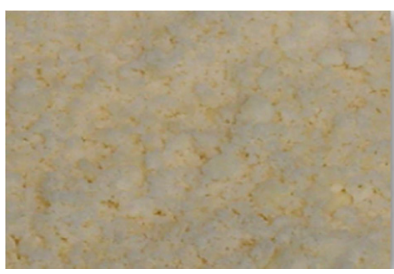

$f$

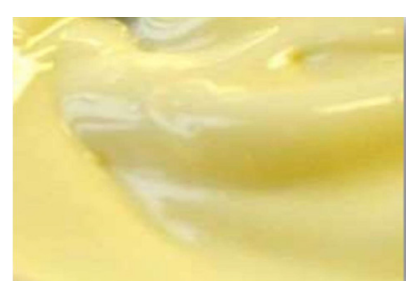

$i$

Fig. 1. Materials of research in the development of a method for obtaining a new generation of protein snacks using a protein base and vegetable fortifiers: $a, b, c, d$-cryo-enrichers from sweet pepper (a), carotene-containing vegetables "Multicarotin" (b), parsley root (c), garlic (d); $\mathrm{e}$ - Nanoadditives from peas, there $\mathrm{f}$ - soft brine cheese after special processing, $\mathrm{g}, \mathrm{h}, \mathrm{i}$ - protein snacks "Bogatyr" (g), "Carotone" (c), "Sviliachok" (and)

A new generation of natural protein snacks has been developed to strengthen the immune system, it is recommended for implementation in large and small food industry enterprises, in restaurant business establishments.

\section{Experiment procedures}

In vegetable raw materials and additives from spicy and carotene-containing vegetables and natural spices, the quality was determined by the content of biologically active substances, in particular:

- L-ascorbic acid, by the method of visual and potentiometric titration with a solution of 2,6-dichlorophenolindophenate $\mathrm{Na}$;

- $\beta$-carotene, by the colorimetric method of Moore after extraction of carotene from the product with an organic solvent and purification of carotene from accompanying colored substances using column chromatography;

- low molecular weight phenolic compounds (for rutin and chlorogenic acids separately), by the colorimetric method of Folin-Denis in terms of rutin and separately for chlorogenic acid;

- polyphenolic compounds, by a titrometric method based on the properties of polyphenolic compounds to oxidize in the presence of the indicator indigo carmine, the calculation of tannins was carried out in terms of tannin.

The processing of the results of experimental studies was carried out using methods of mathematical processing using computer programs MathCad and Microsoft Excel.

\section{Results}

A new method has been developed for obtaining a new generation of protein snacks to strengthen immunity using a protein base and cryo-frozen vegetable fortifiers from spicy and car- 
otene-containing vegetables. The new method is based on the use as an innovation of the method of deep processing of raw materials, which consists in a complex effect on vegetable and protein raw materials of cryo and mechanical destruction processes in modern quick-freezing and low-temperature crushing equipment (at a temperature of $-35^{\circ} \mathrm{C}$ ).

The proposed method allows to preserve, additionally remove and transform into a free easily digestible form of protein, BAS and phytocomponents. So, when receiving cryo-frozen vegetable fortifiers from spicy and carotene-containing vegetables, the mass fraction of BAR and phytocomponents increases 5.0 ... 5.7 times compared to the original fresh raw material. When a protein plant base is obtained from peas in the form of a nanopowder, the amino acids of the protein are transformed into a free, easily digestible form, the percentage of which in the powder is $51 \%$. When a protein milk base is obtained from soft brine cheese, $50 \ldots 55 \%$ of the amino acids bound in the protein molecule are transformed into $\alpha$-amino acids, which are in a free easily digestible form. In addition, it allows the protein base and vegetable enrichment to be provided with new functions of structure formation, gelling, coloring ability, and the like. This makes it possible to obtain new natural protein health-improving snacks with a high content of biologically active substances, phytocomponents, protein and without the use of artificial food additives. The proposed method makes it possible to more fully reveal and use the biological potential of these types of protein and vegetable raw materials, significantly increase the efficiency of the resulting product when consumed by the human body.

When receiving cryo-frozen vegetable fortifiers, it was found that the use of cryogenic "shock" freezing at a rate of $2{ }^{\circ} \mathrm{C} / \mathrm{min}$ to a product temperature of $32 \ldots 35^{\circ} \mathrm{C}$ leads to inactivation of oxidative enzymes. The mechanism of the process is associated with the denaturation and destruction of the protein part of the enzymes, as well as with the inactivation of the active centers of the enzymes.

In addition, the effect of cryo and mechanical destruction processes on the content of biologically active substances and phytocomponents in the production of cryo-frozen vegetable fortifiers from spicy and carotene-containing vegetables was studied in terms of the mass fraction of L-ascorbic acid, $\beta$-picture, phenolic compounds, flavonol glycosides, polyphenols (Table 1).

Table 1

Influence of cryo and mechanical destruction processes on the content of biologically active substances and phytocomponents of spicy and carotene-containing vegetables

\begin{tabular}{|c|c|c|c|c|c|}
\hline \multirow[b]{2}{*}{ Product } & \multicolumn{5}{|c|}{ Mass fraction of BAS, mg per $100 \mathrm{~g}$} \\
\hline & L-ascorbic acid & $\beta$-carotene & $\begin{array}{l}\text { phenolic compounds (by } \\
\text { chlorogenic acid) }\end{array}$ & $\begin{array}{l}\text { flavonol glyco- } \\
\text { sides (by rutin) }\end{array}$ & $\begin{array}{c}\text { polyphenolic } \\
\text { tannins (by } \\
\text { tannin) }\end{array}$ \\
\hline \multicolumn{6}{|c|}{ Parsley root } \\
\hline fresh & $28,4 \ldots 30,1$ & $0,2 \ldots 0,3$ & $305,0 \ldots 321,4$ & $50,6 \ldots 56,7$ & $380,2 \ldots 385,4$ \\
\hline cryoprocessed & $58,6 \ldots 62,5$ & $0,3 \ldots 0,4$ & $506,2 \ldots 529,2$ & $82,7 \ldots 90,3$ & $556,0 \ldots 570,2$ \\
\hline \multicolumn{6}{|c|}{ A mixture of carotene-containing vegetables (carrots, pumpkin, tomatoes) «Multicarotine» } \\
\hline mix of fresh $\mathrm{KBO}^{*}$ & $18,2 \ldots 20,4$ & $8,2 \ldots 10,3$ & $170,1 \ldots 182,3$ & $48,2 \ldots 51,4$ & $240,3 \ldots 250,2$ \\
\hline cryoprocessed & $40,1 \ldots 45,6$ & $30,5 \ldots 32,4$ & $295,3 \ldots 304,2$ & $108,2 \ldots 125,4$ & $390,1 \ldots 425,3$ \\
\hline \multicolumn{6}{|c|}{ Sweet pepper } \\
\hline fresh & $310,0 \ldots 335,0$ & $5,0 \ldots 5,4$ & $132,0 \ldots 150,1$ & $28,5 \ldots 32,4$ & $118,3 \ldots 126,2$ \\
\hline cryoprocessed & $720,2 \ldots 800,4$ & $12,8 \ldots 15,5$ & $204,2 \ldots 210,6$ & $41,0 \ldots 46,3$ & $190,2 \ldots 195,4$ \\
\hline
\end{tabular}

It has been established that the use of cryogenic "shock" freezing of spicy and carotene vegetables to a temperature of $32 \ldots 35^{\circ} \mathrm{C}$ and further fine grinding leads to additional removal of previously unknown forms of BAS from raw materials into a free form, the mass fraction of which is $5.0 \ldots 57$ times more compared to fresh raw materials.

The mechanism of increasing the content of biologically active substances and phytocomponents is associated with the use of cryo and mechanical destruction processes, mechanocracking and transformation of biologically active substances in an easily digestible form. 
The obtained vegetable fortifiers were used in the production of protein snacks not only as BAR fortifiers, but also as natural structurants, gelling agents, dyes and flavorings.

Nano-additives from dried peas and specially processed soft brine cheese were used as a protein base in the manufacture of a new generation of protein snacks to strengthen the immune system.

Additives from peas in the form of powder and puree obtained with the use of nanotechnology based on the use of non-enzymatic catalysis - mechanolysis, mechanical destruction, which makes it possible to obtain additives in an easily digestible nano-sized form. It was shown that the obtained nanoadditives from peas contain $21.5 \ldots 23.0 \%$ of complete protein, of which $51 \%$ of amino acids are in a free state and $49 \%$ are in a bound state.

When using cheese, special processing was carried out using mechanical destruction. It is shown that in soft brine, raw protein for special processing is in a bound form. The use of mechanical destruction leads to the transformation of $50 \ldots 55 \%$ of the amino acids bound in the protein molecule into $\alpha$-amino acids, which are in a free easily digestible form.

A new generation of natural protein snacks has been developed that help to strengthen the immune system using vegetable fortifiers from spicy and carotene vegetables in combination with a protein base (from legumes and soft brine cheese) as recipe components. Natural spice additives in the form of powders and extracts were used as natural preservatives. New types of protein snacks differ from the traditional ones in their high content of biologically active substances, complete protein (more than $18 \%$ ) and the absence of synthetic impurities (preservatives, thickeners, dyes, etc.). In addition, $100 \mathrm{~g}$ of new products can satisfy the daily requirement for biologically active substances ( $\beta$-carotene, L-ascorbic acid, phenolic compounds). New types of protein snacks are unique in chemical composition, natural products, superior in quality to analogues and are recommended for immunoprophylaxis of all segments of the population. In terms of BAS content, the new snacks meet the recommended FAO/WHO criteria for foods for a healthy diet. The obtained protein base and vegetable fortifiers are recommended for use in the manufacture of a wide range of products for a healthy diet.

Health-improving protein snacks have been tested in production conditions at the enterprises of Kharkiv, in particular in LLC” Lisova Kazka “, LLC” KHPK “, UE "Baby food combine”, received a positive assessment and are waiting for their consumer and investor.

\section{Conclusions}

A method for obtaining a new generation of protein snacks for strengthening immunity using a protein vegetable and dairy base and vegetable cryo-frozen fortifiers from spicy and carotene vegetables has been proposed and developed. The new method is based on the use of the method of deep processing of raw materials as an innovation, which consists in the complex effect of cryo and mechanical destruction processes on vegetable and protein raw materials.

The proposed method allows to preserve, additionally remove and transform into a free easily digestible form of protein, BAR and phytocomponents. So, when receiving cryo-frozen vegetable fortifiers from spicy and carotene vegetables, the mass fraction of BAR and phytocomponents increases $5.0 \ldots 5.7$ times compared to the original fresh raw material. When a protein plant base is obtained from peas in the form of a nanopowder, the amino acids of the protein are transformed into a free, easily digestible form, the percentage of which in the powder is $51 \%$. When a protein milk base is obtained from soft brine cheese, $50 \ldots 55 \%$ of the amino acids bound in the protein molecule are transformed into $\alpha$-amino acids, which are in a free easily digestible form. In addition, it allows the protein base and vegetable enrichment to be provided with new functions of structure formation, gelling, coloring ability, and the like. This makes it possible to obtain new natural protein health-improving snacks with a high content of biologically active substances, phytocomponents, protein and without the use of artificial food additives. The proposed method makes it possible to more fully reveal and use the biological potential of these types of protein and vegetable raw materials, significantly increase the efficiency of the resulting product when consumed by the human body.

When receiving cryo-frozen vegetable fortifiers, it was found that the use of cryogenic "shock" freezing using high speeds (including $2{ }^{\circ} \mathrm{C} / \mathrm{min}$ ) up to a temperature inside the product $32 \ldots 35^{\circ} \mathrm{C}$ leads 
to complete inactivation of oxidative enzymes. The mechanism of the process is associated with denaturation and destruction of the protein part of enzymes and inactivation of active centers of enzymes.

It has been established that the use of cryogenic "shock" freezing of spicy and carotene vegetables to a temperature of $32 \ldots 35^{\circ} \mathrm{C}$ and further fine grinding of cryo-frozen vegetables leads to additional withdrawal from raw materials of previously hidden unknown forms of BAS into a free form, the mass fraction of which is 5,0 ... 5.7 times more compared to fresh raw materials. The mechanism of the processes is associated with the use of cryoprocessing processes, cryomechanical destruction, mechanocracking and transformation in an easily digestible form.

A new generation of natural protein snacks has been developed to strengthen the immune system using vegetable fortifiers from spicy and carotene vegetables in combination with a protein base (from legumes, soft brine cheese). The obtained protein snacks differ from the traditional ones in their high content of biologically active substances, complete protein (more than $18 \%$ ), the absence of synthetic impurities (preservatives, thickeners, dyes, etc.) and an extended shelf life. Consumption of $100 \mathrm{~g}$ of new products can satisfy the daily requirement for biologically active substances ( $\beta$-carotene, L-ascorbic acid, phenolic compounds). New types of protein snacks are unique in chemical composition, natural products, superior in quality to world analogues and are recommended for immunoprophylaxis of all segments of the population.

\section{Acknowledgement}

The authors express their gratitude to the Doctor of Technical Sciences, Professor, Honored Worker of Science and Technology of Ukraine, laureate of the State Prize of Ukraine in the field of science and technology, academician of the International Academy of Refrigeration, head of the scientific school and founder of the Department of Food Technologies of Products from Fruit, Vegetables and Milk and Innovations in Wellness. nutrition of the Kharkiv State University of Food Technology and Trade Raisa Pavliuk for the opportunity to work in a team of like-minded people, constant help and scientific advice and the opportunity to extend scientific research on the topics of her scientific school

\section{References}

[1] Dietary protein quality evaluation in human nutrition. Report of an FAO Expert Consultation (2013). Food and agriculture organization of the united nations Rome. Vol. 92. Available at: http://www.fao.org/3/i3124e/i3124e.pdf

[2] Tutel'yan, V. A. (2010). Nauchnye osnovy zdorovogo pitaniya. Moscow: Panorama, 816.

[3] Global strategy on diet, physical activity and health (2004). Fifty-seventh world health assembly. Geneva, 38-55. Available at: https://apps.who.int/gb/ebwha/pdf_files/WHA57/A57_R17-en.pdf

[4] Kontseptsiya Derzhavnoi polityky v haluzi kharchuvannia naselennia Ukrainy (2003). Kharchovi dobavky, inhredienty, BADy: yikh vlastyvosti ta vykorystannia u vyrobnytstvi produktiv i napoiv: nauk. - prakt. konf.: zb. tez dop. Kyiv, 12-18.

[5] Spirichev, V. B., Shatnyuk, L. N., Poznyakovskiy, V. M. (2005). Obogaschenie pischevyh produktov vitaminami i mineral'nymi veschestvami. Novosibirsk: Izd-vo SGU, 548.

[6] Tutel'yan, V. A. (2004). Pitanie i zdorov'e. Pischevaya promyshlennost', 5, 6-7.

[7] Pokrovskiy, V. I. et. al. (2002). Politika zdorovogo pitaniya. Federal'niy i regional'niy uroven'. Novosibirsk: Sib. univ., 258.

[8] Pavlyuk, R., Pogarska, V., Kotuyk, T., Pogarskiy, A., Balabai, K. (2020). Development of nanotechnology for processing chickpeas into protein plant supplements and their use to obtain a new generation of confectionery. Eastern-European Journal of Enterprise Technologies, 6 (11 (108)), 27-36. doi: https://doi.org/10.15587/1729-4061.2020.217928

[9] Patt, V. A., Stolyarova, L. F., Dudareva, T. A. (1980). Obogaschenie hleba gorohovoy mukoy uluchshennogo kachestva. Hlebopekarnaya i konditerskaya promyshlennost', 4, 29-31.

[10] Izbash, Ye. O., Morhun, V. O., Mariniesku, N. H. (2010). Rozrobka parametriv pidhotovky zernovykh dobavok dlia vyrobnytstva molochno-roslynnykh produktiv. Naukovi pratsi ONAKhT. Ser.: Tekhnichni nauky, 2 (38), 265-268.

[11] Shenderov, B. A., Truhanov, A. I. (2002). Produkty funktsional'nogo pitaniya: sovremennoe sostoyanie i perspektivy ih ispol'zovaniya v vosstanovitel'noy meditsine. Vestnik vosstanovitel'noy meditsiny, 1, 38-42.

[12] Pavlyuk, R., Pogarska, V., Yurieva, O., Skripka, L., Abramova, T. (2016). Technology of healthy processed cheese products without melting salts with the use of freezing and non-fermentative catalysis. Eastern-European Journal of Enterprise Technologies, 5 (11 (83)), 51-61. doi: https://doi.org/10.15587/1729-4061.2016.81415 
[13] Pavlyuk, R., Pogarska, V., Timofeyeva, N., Bilenko, L., Stukonozhenko, T. (2016). Exploring the processes of cryomechanodestruction and mechanochemistry when devising nano-technologies for the frozen carotenoid plant supplements. Eastern-European Journal of Enterprise Technologies, 6 (11 (84)), 39-46. doi: https://doi.org/10.15587/1729-4061.2016.86968

[14] Pavlyuk, R., Pogarskaya, V., Cherevko, O., Pavliuk, V., Radchenko, L., Dudnyk, E. et. al. (2018). Studying the complex of biologically active substances in spicy vegetables and designing the nanotechnologies for cryosupplements and nanoproducts with health benefits. Eastern-European Journal of Enterprise Technologies, 4 (11 (94)), 6-14. doi: https://doi.org/10.15587/1729-4061.2018.133819

[15] Pavlyuk, R., Pogarskaya, V., Radchenko, L., Yurieva, O., Gasanova, A., Abramova, A., Kolomiets, T. (2015). The development of technology of nanoextracts and nanopowders from herbal spices for healthful products. Eastern-European Journal of Enterprise Technologies, 3 (10 (75)), 54-59. doi: https://doi.org/10.15587/1729-4061.2015.43323

[16] Topolska, K., Filipiak-Florkiewicz, A., Florkiewicz, A., Cieslik, E. (2016). Fructan stability in strawberry sorbets in dependence on their source and the period of storage. European Food Research and Technology, 243 (4), 701-709. doi: https:// doi.org/10.1007/s00217-016-2783-0

[17] Clarke, C. (2015). The Science of Ice Cream. Royal Society of Chemistry, 527.

[18] Ozdemir, C., Arslaner, A., Ozdemir, S., Allahyari, M. (2015). The production of ice cream using stevia as a sweetener. Journal of Food Science and Technology, 52 (11), 7545-7548. doi: https://doi.org/10.1007/s13197-015-1784-5

[19] Sinha, N. K., H’yu, I. G. (2014). Nastol'naya kniga proizvoditelya i pererabotchika plodoovoschnoy produktsii. Sankt-Peterburg: Professiya, 896.

[20] Stringer, M., Dennis, K. (2004). Ohlazhdennye i zamorozhennye produkty. Sankt-Peterburg: Professiya, 496.

[21] Pavluk, R., Pogarskiy, A., Kaplun, H., Loseva, S. (2015). Developing the cryogenic freezing technology of chlorophyll-containing vegetables. Eastern-European Journal of Enterprise Technologies, 6 (10 (78)), 42-47. doi: https://doi.org/10.15587/1729-4061.2015.56111

[22] Tuan Pham, Q. (2014). Freezing time formulas for foods with low moisture content, low freezing point and for cryogenic freezing. Journal of Food Engineering, 127, 85-92. doi: https://doi.org/10.1016/j.jfoodeng.2013.12.007

[23] James, S. J., James, C. (2014). Chilling and Freezing. Food Safety Management, 481-510. doi: https://doi.org/10.1016/b978-012-381504-0.00020-2

[24] The Effect of Storage Temperature on the Ascorbic Acid Content and Color of Frozen Broad Beans and Cauliflowers and Consumption of electrical Energy during Storage (2015). Gida. The Journal of Food, 11 (5). Available at: https://doaj.org/article/ f6cf2689b10743ff95faa483fd8d6956

[25] Evans, J. (2016). Emerging Refrigeration and Freezing Technologies for Food Preservation. Innovation and Future Trends in Food Manufacturing and Supply Chain Technologies, 175-201. doi: https://oi.org/10.1016/b978-1-78242-447-5.00007-1

[26] Espinoza Rodezno, L. A., Sundararajan, S., Solval, K. M., Chotiko, A., Li, J., Zhang, J. et. al. (2013). Cryogenic and air blast freezing techniques and their effect on the quality of catfish fillets. LWT - Food Science and Technology, 54 (2), 377-382. doi: https://doi.org/10.1016/j.lwt.2013.07.005

[27] Tolstorebrov, I., Eikevik, T. M., Bantle, M. (2016). Effect of low and ultra-low temperature applications during freezing and frozen storage on quality parameters for fish. International Journal of Refrigeration, 63, 37-47. doi: https://doi.org/10.1016/j.ijrefrig.2015.11.003

[28] Misra, N. N., Koubaa, M., Roohinejad, S., Juliano, P., Alpas, H., Inácio, R. S. et. al. (2017). Landmarks in the historical development of twenty first century food processing technologies. Food Research International, 97, 318-339. doi: https://doi. $\operatorname{org} / 10.1016 /$ j.foodres.2017.05.001

[29] Min, K., Chen, K., Arora, R. (2014). Effect of short-term versus prolonged freezing on freeze-thaw injury and post-thaw recovery in spinach: Importance in laboratory freeze-thaw protocols. Environmental and Experimental Botany, 106, $124-131$. doi: https://doi.org/10.1016/j.envexpbot.2014.01.009

[30] Fennema, O. (1978). Cryogenic Freezing of Foods. Advances in Cryogenic Engineering, 712-720. doi: https:// doi.org/10.1007/978-1-4613-4039-3_89

How to cite. Pogarskaya, V., Yurieva, O., Pogarskiy, A., Balabai, K., Maksymova, N. (2021). Development of a method for producing new generation of protein snacks using the processes of cryo and mechanical distruction. EUREKA: Life Sciences, 3, 46-52. doi: https://doi.org/10.21303/2504-5695.2021.001877 